Acta Horticulturae et Regiotecturae - Special Issue

Nitra, Slovaca Universitas Agriculturae Nitriae, 2021, pp. 31-36

\title{
ESTIMATING RAINFALL EROSIVITY FACTOR USING FUTURE CLIMATE PROJECTION IN THE MYJAVA REGION (SLOVAKIA)
}

\author{
Peter VALENT ${ }^{1,2 *}$, Roman VÝLETA ${ }^{2}$ \\ ${ }^{1}$ Vienna University of Technology, Vienna, Austria \\ ${ }^{2}$ Slovak University of Technology in Bratislava, Bratislava, Slovakia
}

\begin{abstract}
Rainfall erosivity factor (R) of the USLE model is one of the most popular indicators of areas potentially susceptible to soil erosion. Its value is influenced by the number and intensity of extreme rainfall events. Since the regional climate models expect that the intensity of heavy rainfall events will increase in the future, the currently used R-factor values are expected to change as well. This study investigates possible changes in the values of R-factor due to climate change in the Myjava region in Slovakia that is severely affected by soil erosion. Two rain gauge stations with high-resolution 1-minute data were used to build a multiple linear regression model $\left(r^{2}=0.98\right)$ between monthly $E I_{30}$ values and other monthly rainfall characteristics derived from low-resolution daily data. The model was used to estimate at-site $R$-values in 13 additional rain gauge stations homogeneously dispersed over the whole region for four periods (1981-2010, 2011-2040, 2041-2070, 2071-2100). The at-site estimates were used to create $R$-factor maps using a geostatistical approach. The results showed that the mean $R$-factor values in the region might change from 429 to as much as $520 \mathrm{MJ} . \mathrm{mm} \cdot \mathrm{ha}^{-1} \cdot \mathrm{h}^{-1} \cdot \mathrm{yr}^{-1}$ in the second half of the $21^{\text {st }}$ century representing a $20.5 \%$ increase.
\end{abstract}

Keywords: R-factor, soil erosion, climate change, ordinary kriging

Soil erosion by water has become one of the greatest environmental threats worldwide. It negatively affects soil quality and fertility by reducing its infiltration rates, water-holding capacity or the nutrient and organic matter contents. The implications are associated not only with reduced agricultural productivity but also with compromised biodiversity, ecosystem services, water quality and quantity and recreational activities (Korbel'ová, Kohnová, 2017; Stolte et al., 2016). In Europe, the most dominant cause of soil loss is induced by water erosion in the form of heavy rainfall episodes (Boardman, Poesen, 2006).

As soil erosion by water is difficult to measure in a regional scale, it is often estimated using empirical models such as the universal soil loss equation (USLE) model (Wischmeier, Smith, 1978). The model estimates mean annual soil loss resulting from the erosive effect of raindrops by multiplying six empirically derived factors from which rainfall erosivity factor $(R)$ has the highest impact (Loureiro, Coutinho, 2001; Panagos et al., 2015). The $R$-factor is a multi-annual average index representing kinetic energy and intensity of high-intensity rainfall events with a potential to cause soil erosion. Its accurate estimation relies on high-temporal-resolution of precipitation records that should be available for 10-20 years at least (Brychta, Janeček, 2019). Since such data is often not available everywhere, several studies emerged to map the spatial distribution of $R$-factor values to promote regional soil erosion assessments and its easy application to land management or soil conservation practices (Angulo-Martínez et al., 2009; Goovaerts, 1999).

In the last years, there were some efforts trying to update $R$-factor values in the Central European region based on the extended datasets in terms of both longer records and denser network of rain gauge stations (Brychta, Janeček, 2019). Studies from Slovakia and the Czech Republic showed that the historically used values were significantly underestimated (Hanel et al., 2016; Onderka, Pecho, 2019) with the updated values twice as large as those historically used.

Despite these updates, several studies have already shown that soil erosion rates might significantly increase in the near future as a result of the expected climate change (Panagos et al., 2017). In Europe, the simulations using regional climate models revealed that the total number of rainfall events will decrease while rainfall intensities will increase especially for extreme rainfall events (Westra et al., 2014). Panagos et al. (2017) predict that these changes might increase the rainfall erosivity factor in Europe by as much as $18 \%$ by the end of 2050, with Central Europe being one of the most affected regions in Europe.

The objective of this study is to estimate the expected change in $R$-factor due to climate change in one of the regions that are most severely affected by soil erosion in Slovakia. Within the study, high-resolution 1-minute rainfall data was used to build a regression model enabling to extend the dataset of rainfall erosive events in the region by

Contact address: Peter Valent, Institute of Hydraulic Engineering and Water Resources Management, Vienna University of Technology, Karlsplatz 13/222, A-1040 Vienna, Austria; J +421(2)32 888 727; e-mail: valent@hydro.tuwien.ac.at 


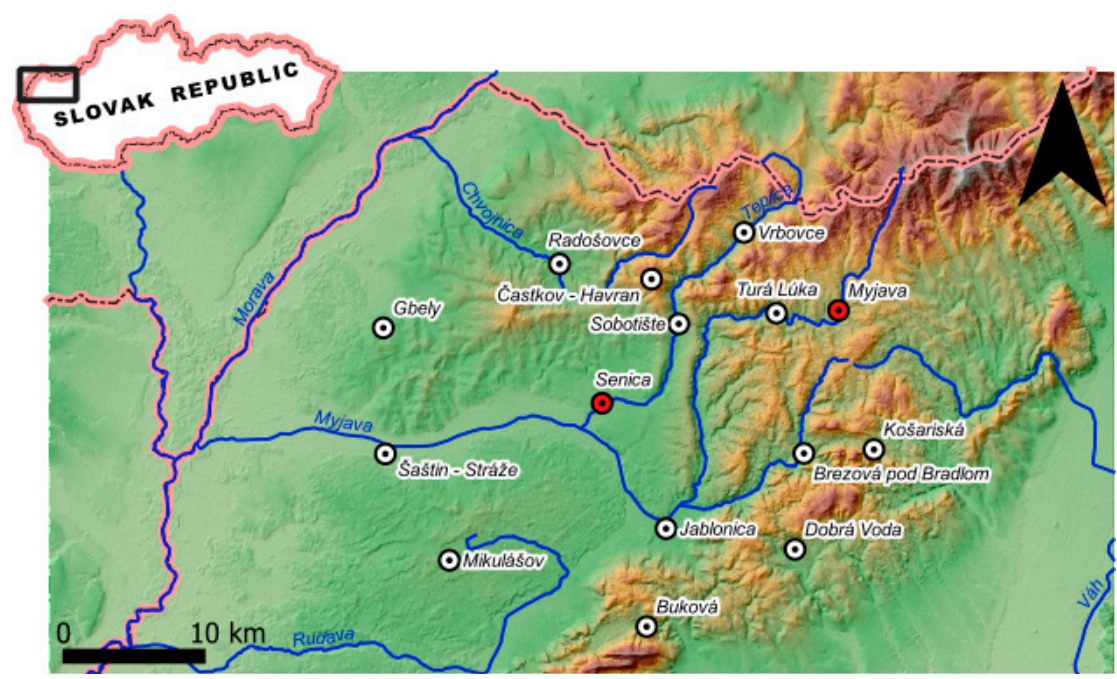

Figure 1 Location of the study area and the position of 15 rain gauge stations used in the analysis. White circles represent stations with low-resolution daily data and red circles with high-resolution 1-minute data

stations for which only low-resolution daily rainfall data were available. The estimated at-site $R$-factor values were spatially interpolated to create rainfall erosivity maps of the region for the current and the three future periods.

\section{Material and method}

\section{Study area}

The area of interest is situated in the western part of Slovakia. It encompasses the geomorphological units of the Myjava Hill Land, Chvojnica Hill Land and the northern part of the Bor Lowlands (Figure 1). The altitude in the area ranges between $160 \mathrm{~m}$ a.s.l. (the western part near the rivers) and $580 \mathrm{~m}$ a.s.l. (northern part in the hills). A large part of the area lies in the Myjava River catchment, which has historically been significantly influenced by anthropogenic processes represented mainly by massive deforestation and subsequent large-scale agriculture. Many of these changes took place in the second half of the $20^{\text {th }}$ century, since when the region has been a subject to increased occurrence of flash floods and significantly intensified erosion processes (Stankoviansky, 2001). The mean annual rainfall in the area varies between 550 and $700 \mathrm{~mm}$, with the mean annual air temperature of $9{ }^{\circ} \mathrm{C}$ (Figure 2). During the winter months, the elevated parts of the area are partially covered with snow that usually melts away with the first spring months.

\section{Observed data}

The rainfall data used in this study were taken from the national meteorological and climatological databases administered by the Slovak Hydrometeorological Institute. The data available come from 15 rain gauges that are evenly distributed over the study
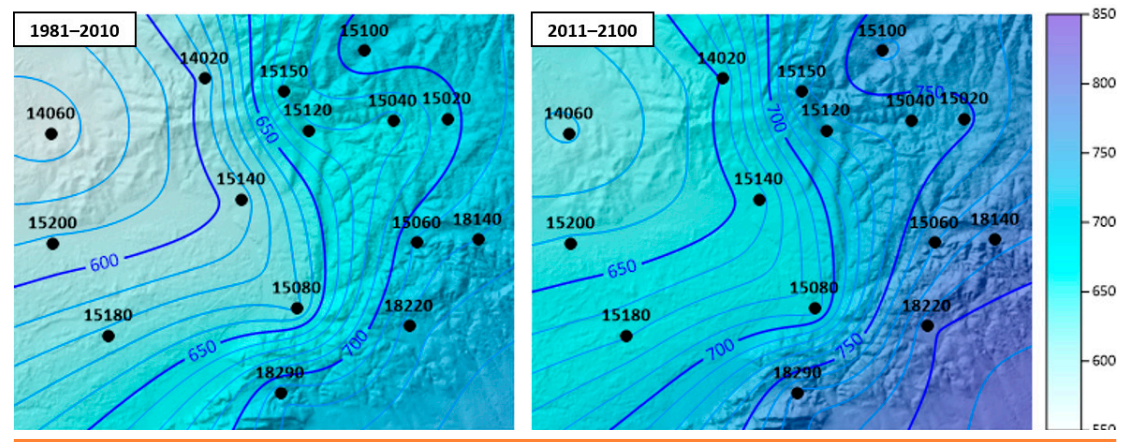

Figure 2 Maps of mean annual precipitation in mm for the current (1980-2010) and the future periods (2011-2100) area (see Figure 1). The elevation of the stations is diverse and represents all elevation zones in the investigated area (see Table 1). For all stations, daily rainfall heights are available for a 30-year period between January $1^{\text {st }}, 1981$ and December $31^{\text {st }}, 2010$. In addition to the daily data, high-resolution tippingbucket rain gauge data in a 1-minute time step was available at Myjava and Senica stations. The high-resolution data covers only the "warm" period of the year when it is ensured that the precipitation occurs exclusively in its liquid state. For this study, this assumption was taken as the rainfall erosivity factor analysed here does not account for the erosive forces of thaw and snowmelt processes (Onderka, Pecho, 2019; Wischmeier, Smith, 1978). The high-resolution data then covers the months from April to October and a 15-year period between April $1^{\text {st }}$, 1995 and October 31 $1^{\text {st }}, 2009$.

\section{Climate change scenarios}

In order to assess the possible changes in the $R$-factor values due to the expected changes in climate, projections of daily precipitation totals for each station were included in the analysis. Scenarios of changes in daily precipitation totals in Slovakia have been prepared using model outputs from the Canadian Global General Circulation Model (GCM) called CGCM3.1 and the ICCP SRES-A1B (moderate) emission scenario, issued in 2011. The results were regionally downscaled using the KNMI (Dutch) Regional Circulation Model (RCM), which is based on the German ECHAM5 GCM boundary conditions (Hlavčová et al., 2015; Lapin et al., 2012). The models were used to prepare projections of daily precipitation totals for a period between 2011 and 2100. The data was split into three 30-year periods.

\section{Estimation of $R$-factor from high-resolution data}

Rainfall erosivity factor $(R)$ is usually determined as the sum of erosive storm index values $\mathrm{El}_{30}$ occurring during a mean year. $E I_{30}$ of each storm is defined as a product of a total storm kinetic energy $(E)$ and the maximum 30-minute rainfall intensity $\left(I_{30}\right)$, where $E$ is in MJ.ha ${ }^{-1}$ and $I_{30}$ in $\mathrm{mm} \cdot \mathrm{h}^{-1}$. As not all of the observed rainfall events have a potential to cause 
Table 1 List of rain gauge stations with the estimated values of mean annual $R$-factors

\begin{tabular}{|c|c|c|c|c|c|c|}
\hline \multirow[t]{2}{*}{ ID } & \multirow[t]{2}{*}{ Location } & \multirow{2}{*}{$\begin{array}{c}\text { Elevation } \\
\text { (m a.s.I) }\end{array}$} & \multicolumn{4}{|c|}{$R$-factor (MJ.mm.ha $\left.{ }^{-1} \cdot h^{-1} \cdot y^{-1}\right)$} \\
\hline & & & $1981-2010$ & 2011-2040 & 2041-2070 & $2071-2100$ \\
\hline 15060 & Brezová pod Bradlom & 290.0 & 455 & 526 & 535 & 522 \\
\hline 18290 & Buková & 336.0 & 519 & 592 & 623 & 621 \\
\hline 15150 & Častkov - Havran & 475.0 & 452 & 548 & 548 & 531 \\
\hline 18220 & Dobrá Voda & 257.0 & 475 & 590 & 607 & 602 \\
\hline 14060 & Gbely & 204.0 & 343 & 440 & 460 & 439 \\
\hline 15080 & Jablonica & 204.0 & 450 & 513 & 523 & 526 \\
\hline 18140 & Košariská & 319.0 & 453 & 522 & 547 & 522 \\
\hline 15180 & Mikulášov & 236.0 & 402 & 497 & 479 & 502 \\
\hline 15020 & Myjava & 349.0 & 435 & 484 & 503 & 484 \\
\hline 14020 & Radošovce & 225.0 & 400 & 487 & 488 & 470 \\
\hline 15200 & Šaštín - Stráže & 172.0 & 353 & 452 & 465 & 453 \\
\hline 15140 & Senica & 195.0 & 372 & 447 & 451 & 437 \\
\hline 15120 & Sobotište & 240.0 & 438 & 527 & 529 & 508 \\
\hline 15040 & Turá Lúka & 295.0 & 421 & 511 & 518 & 502 \\
\hline 15100 & Vrbovce & 310.0 & 467 & 547 & 559 & 542 \\
\hline
\end{tabular}

significant soil erosion, various authors have defined sets of rules to select only those events that can trigger soil erosion (Brychta, Janeček, 2017; Wischmeier, Smith, 1978). Although multiple authors tried to optimize the rules for a particular region, in this study, we decided to stick to the widely used selection criteria for comparative reasons as suggested by Onderka and Pecho (2019). In this study, a rainfall event to be considered as potentially erosive had to match the following criteria:

1. individual rainfall events are separated from each other by at least 6 hours during which no rainfall occurs;

2. a minimum rainfall depth of such event is greater than $12.5 \mathrm{~mm}$;

3. a maximum 15-minute rainfall intensity is greater than $6.25 \mathrm{~mm}$.

After identifying the possible erosive rainfall events in the "warm" period of the year, the calculation of the $R$-factor was conducted using the metric version of the empirical equation that was originally developed by Wischmeier Smith (1978). The high-resolution 1-minute rainfall data was available only in Myjava and Senica rain gauge stations. The $R$-factor was then computed using the following formula:

$$
R=\frac{1}{n} \sum_{j=1}^{n} R \sum_{k=1}^{m j}\left(E I_{30}\right)_{k}
$$

where:

$R \quad$ - an average annual rainfall erosivity (MJ.mm.ha ${ }^{-1} \cdot \mathrm{h}^{-1} \cdot \mathrm{yr}^{-1}$ )

$n \quad$ - the number of years covered by the data records

$m j \quad$ - the number of erosive events of a given year $j$

$\mathrm{El}_{30}$ - the rainfall erosivity index (MJ.mm.ha ${ }^{-1} \cdot \mathrm{h}^{-1}$ ) of a single event $k$
The event erosivity $E I_{30}\left(\mathrm{MJ} \cdot \mathrm{mm} \cdot \mathrm{ha}^{-1} \cdot \mathrm{h}^{-1}\right)$ is defined as:

$$
E I_{30}=\left(\sum_{r=1}^{0} e_{r} v_{r}\right) I_{30}
$$

where:

$e_{r} \quad-$ the unit rainfall energy (MJ.ha ${ }^{-1} \cdot \mathrm{mm}^{-1}$ )

$v_{r} \quad$ - the rainfall volume ( $\mathrm{mm}$ ) during each interval $r$ of rainfall event (in this case 1-minute)

$I_{30}$ is the maximum rainfall intensity during a 30 -minute period of the rainfall event $\left(\mathrm{mm} \cdot \mathrm{h}^{-1}\right)$. The unit rainfall energy $\left(e_{r}\right)$ is calculated for each 1-minute interval as follows:

$$
e_{r}=0.29\left(1-0.72 e^{-0.05 i_{r}}\right)
$$

where:

$i_{r} \quad$ - the rainfall intensity during the interval $\left(\mathrm{mm} \cdot \mathrm{h}^{-1}\right)$

\section{Estimation of $\boldsymbol{R}$-factor from low-resolution data}

In the case only low-resolution data is available, the $R$-factor can also be estimated from daily or monthly values of precipitation. In this study, we used the high-resolution rainfall data from stations Myjava and Senica to build a relationship between the monthly storm erosivity index $\left(E I_{30, \text { month }}\right)$ and two independent variables represented by i) the monthly rainfall height for days where precipitation exceeds $10 \mathrm{~mm}\left(\right.$ rain $\left._{10}\right)$ and ii) the monthly number of days where precipitation exceeds $10 \mathrm{~mm}$ (days $\mathrm{s}_{10}$ ). All the three rainfall parameters were calculated from the highresolution rainfall data in the two stations for the "warm" months only. The $\mathrm{El}_{30 \text {, month }}$ values were computed as the sum of $\mathrm{El}_{30}$ for each erosive storm during the month. The rainfall parameters were then used to build a multiple linear 
regression model with $\mathrm{El}_{30 \text {, month }}$ being the dependent and rain $_{10}$ and days ${ }_{10}$ the independent variables. Such a model has already been successfully used by several authors (Ferreira, Panagopoulos, 2014; Goovaerts, 1999; Loureiro, Coutinho, 2001).

As the two stations with high-resolution rainfall data represent both higher and lower elevation zones in the area of interest, it was reasonable to merge the three rainfall parameters from both stations into one dataset (Goovaerts, 1999; Loureiro, Coutinho, 2001). This should secure that the estimated model parameters could then be used to compute the $\mathrm{El}_{30 \text {, month }}$ values for all stations with low-resolution rainfall data in the region. To estimate the $R$-factor for the stations with only low-resolution data available the rainfall parameters rain 10 and days 10 were computed from the daily data. In the next step, equation (4) was used to compute $E I_{30}$ month values for each month available. As the parameters of the regression model were estimated using data from the "warm" part of the year only, the resulting $R$-factor is a sum of the positive monthly $\mathrm{El}_{30 \text {, month }}$ values for months from April to October (Goovaerts, 1999).

\section{Spatial mapping of $R$-factor}

Different authors have already emphasized the need to extend the traditional at-site analysis of $R$-factor to account for its high spatial variability (Angulo-Martínez et al., 2009; Hanel et al., 2016). This is of large importance as a better understanding of the spatial variability and its relation to environmental variables (Ballabio et al., 2017; Hanel et al., 2016; Meusburger et al., 2012; Panagos et al., 2015) would help to prepare better land management strategies and to identify preferential areas where action against soil erosion is needed. With the advent of Geographic Information Systems (GIS), various interpolation techniques have become available to produce high-quality maps of many different environmental characteristics. From among a large number of methods, many authors have reported that satisfactory results could be obtained using geostatistical methods such as ordinary or universal kriging (Angulo-Martínez et al., 2009; Goovaerts, 1999).

In this study, ordinary kriging was used as the most common type of the kriging method. It relies on a correct estimation of the semivariogram model from the sample data. Since the estimation of the model parameters is based only on 15 observations, this type of model was preferred over the universal kriging or co-kriging, which require larger datasets to account for their increased complexities (Angulo-Martínez et al., 2009). The model uses a simple idea that the unknown erosivity value at the unsampled location is a linear combination of neighbouring observations. The unknown value can then be calculated using:

$$
R^{*}=\sum_{i=1}^{n} \lambda_{i} R_{i}
$$

where:

$R^{*}$ and $R_{i}$ - unknown and observed values respectively

$n \quad-$ the total number of stations used in the interpolation

$\lambda_{i} \quad-$ a weight that is unique for each station
The kriging weights are determined such as to minimize the estimation variance, while ensuring the unbiasedness of the estimator. For more information, the reader is referred to a geostatistical textbook (Isaaks and Srivastava, 1989).

\section{Results and discussion}

In the first step of the analysis, the high-resolution 1-minute rainfall data from stations Senica and Myjava were screened for possible erosive storms. During the "warm" part of the 15-year period, 131 and 140 such storms were identified for the two stations, respectively. This represents approximately 9 erosive storms per year, which complies with similar studies conducted in the region (Onderka, Pecho, 2019). For all the erosive storms identified, three monthly descriptive rainfall

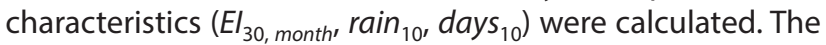
data showed that despite larger mean annual rainfall height in Myjava (Figure 2), the erosive storms from the two stations are very similar in terms of their time of occurrence and characteristics. Because of this, multiple linear regression model between the three rainfall characteristics was fitted using the merged dataset (excluding months without any precipitation). The model was fitted in MATLAB R2019b using its Curve fitting tool. The coefficient of determination $r^{2}$ of the fit was 0.98 meaning that the model used was able to explain most of the variance in $\mathrm{El}_{30 \text {, month }}$. The regression model that was fitted to the merged dataset was given by the following equation:

$$
E I_{30, \text { month }}=3.11 \text { rain }_{10}-26.94 \text { days }_{10}
$$

where:

$\mathrm{El}_{30, \text { month }}$ - the monthly storm erosivity index

rain $_{10}$ - the monthly rainfall height for days where precipitation exceeds $10 \mathrm{~mm}(\mathrm{~mm})$

days $_{10}$ - the monthly number of days where precipitation exceeds $10 \mathrm{~mm}$

Equation (4) shows that the estimated rainfall erosivity is larger in months in which more rainfall falls in lesser number of days.

In the next step, this relationship was used to calculate the values of $\mathrm{El}_{30 \text {, month }}$ from the low-resolution daily data for all the stations in the region. The estimated monthly values for the "warm" months were aggregated for each year and averaged over the 30-year periods of observation and climate scenario projections to get the mean $R$-factor estimates. The estimated $R$-factor values that are given in Table 1 show a significant increase between the current and all the future periods. In average, the difference between the $R$-factor estimated for the current dataset and any of the three climate scenario projection datasets is $+20.5 \%$. This complies with the results presented in Panagos et al. (2017) for Central Europe but is in contrast with the mean annual rainfall totals, where the difference is also positive but only around $+8 \%$ in average (Figure 2). This could be explained by the fact that apart from the slight increase in the rainfall totals, the climate scenario projections also expect the interannual distribution of rainfall will change (Gera et al., 

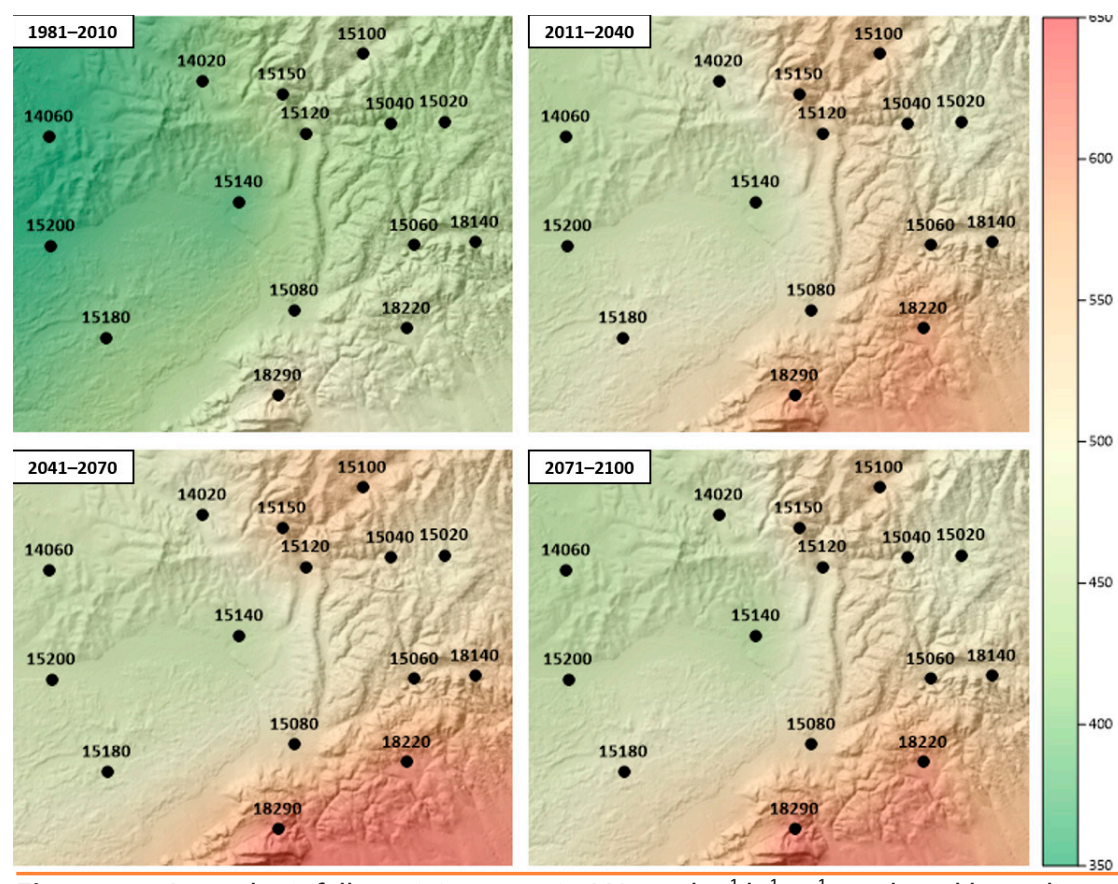

Figure 3 Annual rainfall erosivity maps in $\mathrm{MJ} \cdot \mathrm{mm} \cdot \mathrm{ha}^{-1} \cdot \mathrm{h}^{-1} \cdot \mathrm{yr} \mathrm{r}^{-1}$ produced by ordinary kriging and the estimates of $R$-factors from the low-resolution daily precipitation data

2019; Kohnová et al., 2018; Lapin et al., 2012). The results also indicate that the number and the severity of extreme rainfall events will increase, which will have large implications for not only land management or soil conservation practices, but also the operation of existing water management structures (Rončák et al., 2019). When comparing the three periods of the climate scenario projections, the estimated $R$-factors in the individual stations are very similar without any significant trend observed.

To better understand the spatial pattern of the $R$-factor in the region, ordinary kriging interpolation method was used to perform this task. Analysis of the empirical semivariograms showed that the best model of the semivariogram would be a simple linear model with no nugget effect. Despite the fact that $R$-factor values are very often associated with large spatial variability and temporal variability (Angulo-Martínez et al., 2009; Ballabio et al., 2017), the interpolated surfaces were rather smooth without any interpolation artifacts (see Figure 3). Figure 3 also shows that the $R$-factor follows the same pattern as mean annual rainfall (Figure 2) and gradually increases from west to east. The main reason for this is a strong orographic effect that is present in this region due to the prevailing west-east winds. When looking into the future, the analysis shows that the $R$-factor estimates will increase especially in the mountainous part of the region. This might mainly be problematic for the northern part (around Sobotište, Turá Lúka and Vrbovce), which was subject to the largest anthropogenic changes, accompanied by soil erosion (Hlavčová et al., 2019). In this part of the region, the estimated $R$-factor values will increase from around 420 to as much as $520 \mathrm{MJ} \cdot \mathrm{mm} \cdot \mathrm{ha}^{-1} \cdot \mathrm{h}^{-1} \cdot \mathrm{yr}^{-1}$.

\section{Conclusions}

This study investigates the expected impact of climate change on mean annual rainfall erosivity factor $(R)$ used in the USLE model. The analysis tried to compare the $R$-factor values estimated for four 30-year periods: one representing the current period (19812010) and three the future periods (2011-2040, 2041-2070, 2071-2100). $R$-factor values for the specific periods were estimated from daily precipitation data based on a relationship build between three monthly rainfall characteristics estimated directly from high-resolution 1-minute precipitation data. The biggest changes could be observed between the current and any of the three future periods, where the $R$-factor values increased by as much as $20.5 \%$ in all stations. This might have severe consequences for the future development of the region as its northern part is already a subject to severe soil erosion. It is also a part of the region with multiple mid- to large-scale agricultural and forestry businesses, which might be threatened by the expected rise of soil erosion. This increase in $R$-factor for the future periods could be tracked down to the increased frequency of heavy precipitation days with higher rainfall intensities as projected by the regional climate model.

The information about the spatial distribution of the $R$-factor in this region is of great value as it is a very popular place for site, local or regional erosion studies (Németová et al., 2020; Nosko et al., 2019; Stankoviansky, 2003; Valent, Výleta and Danáčová, 2019). As many of these studies utilize a GIS implementation of the USLE model, the accuracy of the spatial distribution of the $R$-factor plays an important role in minimizing the uncertainties of soil loss estimates.

Further research should focus on finding additional independent variables that could be used to improve the reliability of $\mathrm{El}_{30 \text {, month }}$ estimates from daily rainfall data. Moreover, additional spatial interpolation methods could be tested, including those utilizing secondary variables such as elevation or rainfall to further reduce the estimation variance.

\section{Acknowledgements}

This work was supported by the Slovak Research and Development Agency under the contract No. APVV-19-0340 and the Slovak Science Grant Agency under the contract No. VEGA 1-063219. The authors thank the agencies for their financial support.

\section{References}

Angulo-Martínez, M., López-Vicente, M., Vicente-Serrano, S. M., Beguería, S. (2009). Mapping rainfall erosivity at a regional scale: A comparison of interpolation methods in the Ebro Basin (NE Spain). Hydrology and Earth System Sciences, 13(10), 1907-1920. https://doi.org/10.5194/hess-13-1907-2009 Ballabio, C., Borrelli, P., Spinoni, J., Meusburger, K., Michaelides, S., Beguería, S., ... \& Aalto, J. (2017). Mapping monthly rainfall erosivity in Europe. Science of the Total 
Environment, 579. https://doi.org/10.1016/j.scitotenv.2016.11.123 Boardman, J., Poesen, J. (Eds.). (2006). Soil Erosion in Europe Chichester: John Wiley and Sons, Ltd.

Brychta, J., Janeček, M. (2017). Evaluation of discrepancies in spatial distribution of rainfall erosivity in the Czech Republic caused by different approaches using GIS and geostatistical tools. Soil and Water Research, 12(2), 117-127. https://doi.org/10.17221/176/2015-SWR

Brychta, J., Janeček, M. (2019). Determination of erosion rainfall criteria based on natural rainfall measurement and its impact on spatial distribution of rainfall erosivity in the Czech Republic. Soil and Water Research, 14(3), 153-162. https://doi.org/10.17221/91/2018-SWR

Ferreira, V., Panagopoulos, T. (2014). Seasonality of Soil Erosion Under Mediterranean Conditions at the Alqueva Dam Watershed. Environmental Management, 54(1), 67-83. https://doi.org/10.1007/ s00267-014-0281-3

Gera, M., Damborská, I., Lapin, M., Melo, M. (2019). Climate Changes in Slovakia: Analysis of Past and Present Observations and Scenarios of Future Developments. In Negm, A. M. - Zeleňáková, M. (Eds.), Water Resources in Slovakia: Part II: Climate Change, Drought and Floods (pp. 21-47). https://doi.org/10.1007/698 2017 157

Goovaerts, P. (1999). Using elevation to aid the geostatistical mapping of rainfall erosivity. CATENA, 34(3-4), 227-242. https://doi. org/10.1016/S0341-8162(98)00116-7

Hanel, M., Máca, P., Bašta, P., Vlnas, R., Pech, P. (2016). The rainfall erosivity factor in the Czech Republic and its uncertainty. Hydrology and Earth System Sciences, 20(10), 4307-4322. https://doi. org/10.5194/hess-20-4307-2016

Hlavčová, K., Lapin, M., Valent, P., Szolgay, J., Kohnová, S., Rončák, P. (2015). Estimation of the impact of climate changeinduced extreme precipitation events on floods. Contributions to Geophysics and Geodesy, 45(3), 173-192. https://doi.org/10.1515/ congeo-2015-0019

Hlavčová, K., Danáčová, M., Kohnová, S., Szolgay, J., Valent, P., Výleta, R. (2019). Estimating the effectiveness of crop management on reducing flood risk and sediment transport on hilly agricultural land - A Myjava case study, Slovakia. CATENA, 172, 678-690. https://doi.org/10.1016/J.CATENA.2018.09.027

Isaaks, E. H., Srivastava, M. R. (1989). Applied Geostatistics. New York: Oxford University Press.

Kohnová, S., Vasilaki, M., Hanel, M., Szolgay, J., Hlavčová, K., Loukas, A., Földes, G. (2018). Detection of future changes in trends and scaling exponents in extreme short-term rainfall at selected stations in Slovakia. Contributions to Geophysics and Geodesy, 48(3), 207-230. https://doi.org/10.2478/congeo-2018-0009

Korbel'ová, L., Kohnová, S. (2017). Methods for Improvement of the Ecosystem Services of Soil by Sustainable Land Management in the Myjava River Basin. Slovak Journal of Civil Engineering, 25(1), 29-36. https://doi.org/10.1515/sjce-2017-0005

Lapin, M., Bašták, I., Gera, M., Hrvol', J., Kremler, M., Melo, M. (2012). New climate change scenarios for Slovakia based on global and regional general circulation models. Acta Meteorologica Universitatis Comenianae, 37, 25-73.

Loureiro, N. de S., Coutinho, M. de A. (2001). A new procedure to estimate the RUSLE EI30 index, based on monthly rainfall data and applied to the Algarve region, Portugal. Journal of Hydrology, 250(1-4), 12-18. https://doi.org/10.1016/S0022-1694(01)00387-0
Meusburger, K., Steel, A., Panagos, P., Montanarella, L., Alewell, C. (2012). Spatial and temporal variability of rainfall erosivity factor for Switzerland. Hydrology and Earth System Sciences, 16(1), 167-177. https://doi.org/10.5194/hess-16-167-2012

Németová, Z., Honek, D., Kohnová, S., Hlavčová, K., Šulc Michalková, M., Sočuvka, V., Velísková, Y. (2020). Validation of the EROSION-3D Model through Measured Bathymetric Sediments. Water, 12(4), 1082. https://doi.org/10.3390/w12041082

Nosko, R., Maliariková, M., Brziak, A., Kubáň, M. (2019). Formation of Gully Erosion in the Myjava Region. Slovak Journal of Civil Engineering, 27(3), 63-72. https://doi.org/10.2478/sjce-2019-0023

Onderka, M., Pecho, J. (2019). Update of the erosive rain factor in Slovakia using data from the period 1961-2009. Contributions to Geophysics and Geodesy, 49(3), 355-371. https://doi.org/10.2478/ congeo-2019-0018

Panagos, P., Ballabio, C., Borrelli, P., Meusburger, K., Klik, A., Rousseva, S., ... \& Aalto, J. (2015). Rainfall erosivity in Europe. Science of the Total Environment, 511, 801-814. https://doi.org/10.1016/j. scitotenv.2015.01.008

Panagos, P., Ballabio, C., Meusburger, K., Spinoni, J., Alewell, C., Borrelli, P. (2017). Towards estimates of future rainfall erosivity in Europe based on REDES and WorldClim datasets. Journal of Hydrology, 548, 251-262. https://doi.org/10.1016/j.jhydrol.2017.03.006

Rončák, P., Hlavčová, K., Kohnová, S., Szolgay, J. (2019). Impacts of Future Climate Change on Runoff in Selected Catchments of Slovakia. In Leal Filho, W., Trbic, G., Filipovic, D. (Eds.). Climate Change Adaptation in Eastern Europe: Managing Risks and Building Resilience to Climate Change (pp. 279-292). https://doi. org/10.1007/978-3-030-03383-5_19

Stankoviansky, M. (2001). Erózia z orania a jej geomorfologický efekt s osobitým zretelom na Myjavsko-Bielokarpatskú kopaničiarsku oblast'. Geografický časopis, 53(2), 95-110.

Stankoviansky, M. (2003). Historical evolution of permanent gullies in the Myjava Hill Land, Slovakia. CATENA, 51(3), 223-239. https:// doi.org/10.1016/S0341-8162(02)00167-4

Stolte, J., Tesfai, M., Oygarden, L., Kvaerno, S., Keizer, J., Verheijen, F., ... \& Hessel, R. (2016). Soil threats in Europe: status, methods, drivers and effects on ecosystem services: deliverable 2.1 RECARE project. European Commission DG Joint Research Centre.

Valent, P., Výleta, R., Danáčová, M. (2019). A Joint SedimentationFlood Retention Assessment of a Small Water Reservoir in Slovakia: A New Hope for Old Reservoirs? Geosciences, 9(4), 158. https://doi. org/10.3390/geosciences 9040158

Westra, S., Fowler, H. J., Evans, J. P., Alexander, L. V., Berg, P., Johnson, F., ... \& Roberts, N. M. (2014). Future changes to the intensity and frequency of short-duration extreme rainfall. Reviews of Geophysics, 52(3), 522-555. https://doi.org/10.1002/2014RG000464

Wischmeier, W. H., Smith, D. D. (1978). Predicting Rainfall Erosion Losses: A Guide to Conservation Planning. Washington, D.C.: USDASEA (p. 58). 